\title{
Cotton fibers bleaching through in situ electrochemical generation of oxidant agents
}

\author{
Branqueamento de fibras de algodão através da geração eletroquímica in situ de agentes oxidantes \\ Blanqueo de fibras de algodón mediante la generación electroquímica in situ de agentes oxidantes
}

Received: 07/30/2021 | Reviewed: 08/03/2021 | Accept: 08/07/2021 | Published: 08/13/2021

\author{
Carolline Schreiber \\ ORCID: https://orcid.org/0000-0001-9328-4775 \\ Federal University of Santa Catarina, Brazil \\ E-mail: carollineschreiber@gmail.com \\ Eduardo Zapp \\ ORCID: https://orcid.org/0000-0002-5578-4047 \\ Federal University of Santa Catarina, Brazil \\ E-mail: eduardo.zapp@ufsc.br \\ Cátia Rosana Lange de Aguiar \\ ORCID: https://orcid.org/0000-0003-4142-3619 \\ Federal University of Santa Catarina, Brazil \\ E-mail: catia.lange@ufsc.br \\ Patrícia Bulegon Brondani \\ ORCID: https://orcid.org/0000-0003-4786-8627 \\ Federal University of Santa Catarina, Brazil \\ E-mail: p.b.brondani@ufsc.br
}

\begin{abstract}
Cotton is the world's leading fiber crop and contains natural coloring impurities which need to be removed by bleaching. The most applied bleaching methodology utilizes chemical oxidants, such as hydrogen peroxide. This method is carried out at high temperatures and under strong alkaline conditions, entailing high-energy consumption, strong alkaline effluents and severe fiber damage. The development of milder and greener bleaching processes, in which the fibers are less damaged, is a goal that has long been pursued. Another approach for cotton bleaching is the use of sodium hypochlorite as an oxidant. Several methods applying hypochlorite are known, but they face problems associated with the transport, storage and handling of unstable and hazardous chemicals. Here we present a mild methodology for in situ electrogeneration of hypochlorite from sodium chloride or potassium chloride, and its application in bleaching of cotton, thus reducing the problems associated with the transport and storage of the oxidizing reagent. Our methodology was able to bleach the cotton fibers with a comparable whiteness degree, when compared to the conventional one, and it is carried out in lower reaction times, at room temperature, with no need of addition of hazardous materials and avoiding the production of residual hypochlorite.
\end{abstract}

Keywords: Hypochlorite electrogeneration; Cotton bleaching; Mild bleaching methodology; Chemical waste minimization; Textile industry.

\section{Resumo}

O algodão é a cultura de fibra líder mundial e contém impurezas corantes naturais que precisam ser removidas pelo branqueamento. A metodologia de branqueamento mais aplicada utiliza oxidantes químicos, como o peróxido de hidrogênio. Este método é realizado em altas temperaturas e sob fortes condições alcalinas, acarretando alto consumo de energia, efluentes com elevada alcalinidade e severos danos às fibras. O desenvolvimento de processos de branqueamento mais suaves e verdes, nos quais as fibras são menos danificadas, é uma meta que há muito tempo vem sendo buscada. Outra abordagem para o branqueamento do algodão é o uso de hipoclorito de sódio como oxidante. Vários métodos aplicando hipoclorito são conhecidos, mas enfrentam problemas associados ao transporte, armazenamento e manuseio de produtos químicos instáveis e perigosos. Apresentamos aqui uma metodologia mais branda para a eletrogeração in situ de hipoclorito a partir de cloreto de sódio ou cloreto de potássio, e sua aplicação no branqueamento do algodão, reduzindo assim os problemas associados ao transporte e armazenamento do reagente oxidante. Nossa metodologia foi capaz de branquear as fibras de algodão com grau de alvura comparável ao método convencional, sendo realizada em menores tempos de reação, à temperatura ambiente, sem necessidade de adição de materiais perigosos e evitando a produção de resíduos.

Palavras-chave: Eletrogeração de hipoclorito; Branqueamento do algodão; Metodologia de branqueamento suave; Minimização de resíduos químicos; Indústria têxtil. 


\section{Resumen}

El algodón es el cultivo de fibra líder en el mundo y contiene impurezas colorantes naturales que deben eliminarse mediante blanqueamiento. La metodología de blanqueo más comúnmente aplicada hace uso de oxidantes químicos, como el peróxido de hidrógeno. El proceso se lleva a cabo bajo altas temperaturas y fuertes condiciones alcalinas, que resultan en un gran consumo de energía, efluentes con elevada alcalinidad y severos daños a las fibras. Desarrollar procesos de blanqueo más suaves y ecológicos, en los que las fibras se dañen menos, es un objetivo que se ha perseguido durante mucho tiempo. Otra estrategia para el blanqueo de algodón es el empleo de hipoclorito de sodio como oxidante. Se conocen varios métodos que llevan hipoclorito, pero estos enfrentan problemas asociados al transporte, almacenamiento y manejo de productos químicos inestables y peligrosos. Presentamos aquí una metodología más blanda para la electrogeneración in situ de hipoclorito a partir de cloruro de sodio o cloruro de potasio, y su aplicación en el blanqueo de algodón, reduciendo así los problemas asociados con el transporte y almacenamiento del reactivo oxidante. Nuestra metodología fue capaz de blanquear fibras de algodón hasta un grado de blancura comparable al método convencional, pero en tiempos de reacción más cortos, a temperatura ambiente, sin necesidad de añadir materiales peligrosos y evitando la producción de residuos.

Palabras clave: Electrogeneración de hipoclorito; Blanqueo de algodón; Metodología de blanqueo suave; Minimización de residuos químicos; Industria textil.

\section{Introduction}

Cotton is the world's leading fiber crop, and it is cultivated or processed in many countries (Bahtiyari \& Benli, 2019). The popularity of cotton fiber may be related to its comfortable wearability, due to the excellent properties of its major constituent cellulose, such as higher water and moisture absorbency (Abdel-Halim, 2012; Liu et al., 2018). Raw cotton contains natural coloring impurities including pectin, pigments and cotton wax, which need to be removed by bleaching before the preparation of cotton-based textiles (Bahtiyari \& Benli, 2019; Liu et al., 2018). The objective of the bleaching process is to produce white fabrics by destroying the pigments on the fiber causing minimum degradation to the fiber structures (Abdel-Halim, 2012).

The natural coloring matter can be degraded by oxidative or by reductive processes, or even as a combination of both. Usually, oxidative bleaching is preferred over the reductive process due to the durability of the whiteness produced. Within the oxidative methods, the one applying hydrogen peroxide $\left(\mathrm{H}_{2} \mathrm{O}_{2}\right)$ is the most commonly applied. A key reason why $\mathrm{H}_{2} \mathrm{O}_{2}$ is the main industrial bleaching agent is its classification as eco-friendly when compared to other conventional chlorine oxidizing agent such as sodium hypochlorite (Bahtiyari \& Benli, 2019; Liu et al., 2018; Yu et al., 2018). However, cotton bleaching applying $\mathrm{H}_{2} \mathrm{O}_{2}$ is usually carried out at high temperatures $\left(90-100^{\circ} \mathrm{C}\right)$ and under strong alkaline conditions. This methodology means that the process will have high-energy consumption, produce strong alkaline effluents and result in severe fiber damage (Liu et al., 2018; Yu et al., 2018). In addition, the operational $\mathrm{pH}$ system and the unreacted $\mathrm{H}_{2} \mathrm{O}_{2}$ applied demand significant fresh water for rinsing the fabrics after bleaching, since the residual alkali and $\mathrm{H}_{2} \mathrm{O}_{2}$ on the fabric pose a negative impact on the effectiveness of the subsequent dyeing or finishing processes. Furthermore, the alkali medium bath will account for substantial damage of the cellulosic substrate (Yu et al., 2018).

The development of milder and greener processes for cotton bleaching is a goal that has long been pursued. Ideally, these processes would operate at lower temperatures, have shorter reaction times, and generate smaller amounts of chemical effluents, consuming less water during the whole process and damaging the fiber at a lower level. Even applying oxidant agents other than $\mathrm{H}_{2} \mathrm{O}_{2}$, such as the ones based in chloride ions, if the cited characteristics are respected, a greener process will be achieved.

The main problem with the application of the methods based on chloride oxidants for the bleaching of cotton is the transport, storage and handling of unstable and hazardous chemicals (Vitero et al., 2017). However, if the active bleaching agent can be generated in situ and through a mild methodology, the applicability for industrial purposes will be increased.

The application of electrochemistry for the in situ generation of several chemicals is widely known and these techniques have been used for a long time to solve several technical problems of the textile industry. Applications such as the obtaining of 
functionalized fabrics, the degradation of dyes or even the bleaching of fabrics are known (Das et al., 2016; Sala \& GutiérrezBouzán, 2012; Shetti et al., 2019). The application is due to the fact that, in general, the electrochemical methods are cleaner than, for example, the physicochemical processes (Sala \& Gutiérrez-Bouzán, 2012). They can also be applied in industrial scale, even in combination with a washing machine (Griesbach et al., 2016).

The in situ production of hydrogen peroxide by the electrolysis of oxygen in alkaline medium and its application in the bleaching of fabric is already known, and has been presented in a work in which the authors still applied sodium hydroxide as electrolyte in a process combining scouring and bleaching (Chong, 1998). The electrochemical generation of sodium hypochlorite from sodium chloride and its application in the bleaching of cotton was also performed. In the proposed methodology, the total time for the procedure was $2 \mathrm{~h}$, longer than the $1 \mathrm{~h}$ needed for the traditional bleaching with $\mathrm{H}_{2} \mathrm{O}_{2}(\mathrm{Vitero}$ et al., 2017).

Regarding the electrogeneration of hypochlorite, despite the small number of examples of its applicability toward bleaching processes, several studies have been conducted for other purposes. For example, the generation of $\mathrm{NaClO}$ from $\mathrm{NaCl}$ using $\mathrm{Pb} / \mathrm{PbO}_{2}$ and $\mathrm{C} / \mathrm{PbO}_{2}$ modified electrodes (Ghalwa et al., 2012) or titanium electrode (Saleem et al., 2012).

Here we present a study focusing in the in situ generation of $\mathrm{NaClO}$ through electrochemical techniques and its directed application in the bleaching process of cotton fabric. The main goal of this work is to develop a shorter and milder method for efficiently performing the bleaching of cotton while generating fewer chemical effluents.

\section{Methodology}

In this work, the research methodology used was experimental/laboratory, supported by quantitative and qualitative approaches, aiming to evaluate, from the data obtained, the electrogeneration process of an oxidizing agent applied to the bleaching of cotton fibers (Abdel-Halim, 2012; Das et al., 2016; Ghalwa et al., 2012; Vitero et al., 2017). Next, we describe the materials, processes and the set of analyzes used to assess the feasibility and efficiency of the bleaching process employing in situ electrogeneration of hypochlorite as an oxidizing agent.

\subsection{Materials}

The fabric used in the experiments was a $100 \%$ cotton knitted fabric, with 258 yarn/cm determined by multiplying the number of course and wales measured based on the Brazilian norm NBR 12060 (ABNT, 1991). Density knitted fabric refers to the amount of mass in grams (g) per unit area (ABNT, 2008), and was calculated using samples of 10x10 cm, obtaining a value equal to $200 \mathrm{~g} / \mathrm{m}^{2}$ measured based on the Brazilian norms NBR 10591 (ABNT, 2008) and NBR 12060 (ABNT, 1991).

The electrochemical reactions were carried out using Autolab PGSTAT204 potentiostat/galvanostat (Metrohm). In the experiments applying platinum $(\mathrm{Pt}), \mathrm{tin} / \mathrm{lead}(\mathrm{Sn} / \mathrm{Pb}) 70 / 30(\mathrm{w} / \mathrm{w})$ or carbon rod as working electrodes the counter electrode used was platinum. When aluminum $(\mathrm{Al})$ or stainless steel were used as working electrodes, the counter electrode was the same material as working electrode. The systems always used $\mathrm{Ag} / \mathrm{AgCl}$ as reference electrode to control the applied potential.

Hydrogen peroxide $\left(\mathrm{H}_{2} \mathrm{O}_{2}\right)$ and sodium hypochlorite $(\mathrm{NaClO})$ were used as oxidant agents. Monosodium phosphate $\left(\mathrm{NaH}_{2} \mathrm{PO}_{4}\right)$, disodium phosphate $\left(\mathrm{Na}_{2} \mathrm{HPO}_{4}\right)$, monopotassium phosphate $\left(\mathrm{KH}_{2} \mathrm{PO}_{4}\right)$, sodium bicarbonate $\left(\mathrm{NaHCO}_{3}\right)$ and decahydrate sodium carbonate $\left(\mathrm{Na}_{2} \mathrm{CO}_{3} \cdot 10 \mathrm{H}_{2} \mathrm{O}\right)$ were used at buffers solutions. Sodium chloride $(\mathrm{NaCl})$ and potassium chloride $(\mathrm{KCl})$ were used as electrolytes. Sodium hydroxide $(\mathrm{NaOH})$ and sodium bisulfate $\left(\mathrm{NaHSO}_{3}\right)$ were applied as alkali. Potassium iodate $\left(\mathrm{KIO}_{3}\right)$, potassium iodide $(\mathrm{KI})$, hydrochloric acid $(\mathrm{HCl})$, glacial acetic acid $\left(\mathrm{CH}_{3} \mathrm{COOH}\right)$ and starch were used to determine the amount of active chlorine in the solutions. All chemical reagents were obtained commercially (from Synth or Vetec) and were used without previous purification. All the solutions were prepared with deionized water. 
Iron sequestrant (WK Complex Fe-2), calcium and magnesium sequestrant (ColorsperseDSP 1098), detergent (OPTAVON NW-BR) and detergent/emulsifier (ColorswetDTU-M) were used in electrochemical and conventional experiments as auxiliary products. All auxiliary products were supplied by Color Química do Brasil.

\subsection{Bleaching procedure}

Raw cotton fabric samples were bleached by electrochemical treatment. The conventional treatments in the presence of hydrogen peroxide or sodium hypochlorite were also performed for comparative purposes.

\subsubsection{Electrochemical method}

Electrochemical experiments and their control reactions (without an applied potential) were performed at room temperature. Electrochemical experiments were adapted from Das and collaborators (2016), a fixed potential of $2.5 \mathrm{~V}$ was applied. The electrodes were $1 \mathrm{~cm}$ apart from each other in a cell containing $20 \mathrm{~mL}$ of electrolyte solutions. The superficial area of the cotton in contact with the electrolyte solution was approximately $20 \mathrm{~cm}^{2}$ and the solution was constantly stirred.

Preliminary tests (60 min time interval) were performed in order to define the best electrode system. The best pH's system ( $\mathrm{pH} 7,8,9.3$ or 10) was defined in 15 min tests.

The experiments of oxidation of chloride ions were carried out applying sodium chloride or potassium chloride first in an aqueous medium to understand the efficiency of auxiliary products and later with similar $\mathrm{pH}$ condition as conventional bleaching $(\mathrm{pH} 10)$. The reaction time $(15,30,45$ and $60 \mathrm{~min})$ and the amount of electrolyte (10, 20, 30 and $40 \mathrm{~g} / \mathrm{L})$ were varied.

\subsubsection{Conventional method}

The conventional bleaching tests were carried out in a dyeing machine HT-TC 2200 (Texcontrol), using a material to liquor ratio of 1:20. After bleaching process samples were cold washed for 3 minutes and then dried and weighted.

\subsubsection{Conventional method applying hydrogen peroxide}

The reaction mixture included $\mathrm{NaOH} 50 \%(3 \mathrm{~g} / \mathrm{L}), \mathrm{H}_{2} \mathrm{O}_{2} 50 \%(3 \mathrm{~g} / \mathrm{L})$, Iron sequestrant $(3 \mathrm{~g} / \mathrm{L})$ and detergent $(2 \mathrm{~g} / \mathrm{L})$ at $\mathrm{pH} 11$ for $60 \mathrm{~min}$ after increasing the temperature by $3{ }^{\circ} \mathrm{C} / \mathrm{min}$ to $90{ }^{\circ} \mathrm{C}$, adapted from Bahtiyari and Benli (2019).

\subsubsection{Conventional method applying sodium hypochlorite}

The reaction mixture included $\mathrm{NaOH} 50 \%$ (necessary to reach pH 9.5 - approximately $0.5 \mathrm{~g} / \mathrm{L}$ ), $\mathrm{NaClO}$ (necessary to reach $3 \mathrm{~g} / \mathrm{L}$ active Chlorine - approximately $0.6 \mathrm{~g} / \mathrm{L})$ and detergent $(1 \mathrm{~g} / \mathrm{L})$ for $60 \mathrm{~min}$ at $25^{\circ} \mathrm{C}$. After this $\mathrm{NaHSO}_{3}(2 \mathrm{~g} / \mathrm{L})$ was added and the experiment carried out for more $30 \mathrm{~min}$ at $30^{\circ} \mathrm{C}$, adapted from Das and collaborators (2016).

\subsection{Testing and analysis}

\subsubsection{Weight loss}

Fabric weight loss was calculated on the basis of dry weight using the following equation: Weight lost $(\%)=[(\mathrm{Z} 1-$ Z2)/Z1]*100 where Z1 and Z2 are the dry weights of the fiber before and after bleaching treatment, respectively. This methodology was based in the literature (Abdel-Halim, 2012; Abdel-Halim, 2013). 


\subsubsection{Degree of whiteness}

The efficiency of bleaching was checked by calculating the whiteness Index through the spectrophotometer. The whiteness index (Berger) of the fabric was determined using a reflectance measuring Datacolor apparatus at standard illuminant D65/10 (Farooq et al., 2013). The initial Berger degree of raw cotton fabric was 11.19.

\subsubsection{Hydrophilicity}

The time a water drop takes to be absorbed by the tissue was analyzed and the approximate hydrophilicity was determined based on the Brazilian norms NBR 13000 (ABNT, 1993).

\section{Results and Discussion}

\subsection{Proposed hypochlorite electrogeneration mechanism and bleaching process}

Based in the more commonly applied bleaching process, preliminary experiments regarding the electrogeneration of hydroxyl radical from water, even in the presence of a small amount of $\mathrm{H}_{2} \mathrm{O}_{2}$ and $\mathrm{NaOH}$, were performed. These reactions were tested applying different pH medium (7-10) and different electrodes. Despite all the tests, no outstanding results were observed.

The bleaching processes applying hypochlorite are less common than the ones based on $\mathrm{H}_{2} \mathrm{O}_{2}$, mainly because of transportation and storage safety issues. However, if the production of the active bleaching reactant could be performed in situ, these issues should be addressed.

It is known that in the presence of chloride ions in an aqueous medium, in situ controlled hypochlorite electrogeneration is possible, generating a strong oxidizing power that can be used in fabric bleaching (Ciobotaru et al., 2020; Das et al., 2016; Vitero et al., 2017). When a flow of electricity is applied to a solution containing chloride ions, a set of chlorine-containing oxidants is produced from anodic reactions, generating active chlorine in the medium. This reaction begins with the oxidation of the chloride ions to form chlorine gas $\left(\mathrm{Cl}_{2}\right)$ (Equation 1), which is then diffused into the solution, resulting in the generation of the hypochlorite ion $\left(\mathrm{ClO}^{-}\right)$(Equation 3$)$ in an alkaline medium. The alkalinization of the medium is achieved due to the cathodic reaction involving the reduction of water leading to hydrogen and hydroxyl ions generation (Equation 2) (Ciobotaru et al., 2020; Das et al., 2016; Vitero et al., 2017).

$\begin{array}{lll}\text { Anode half-reaction: } 2 \mathrm{Cl}^{-} \leftrightharpoons \mathrm{Cl}_{2}+2 \mathrm{e}^{-} & \mathrm{E}^{\mathrm{o}}=1.358 \mathrm{~V} & \text { (Equation 1) } \\ \text { Cathode half-reaction: } 2 \mathrm{H}_{2} \mathrm{O}+2 \mathrm{e}^{-} \leftrightharpoons 2 \mathrm{OH}^{-}+\mathrm{H}_{2} & \mathrm{E}^{\mathrm{o}}=-0.8277 \mathrm{~V} & \text { (Equation 2) } \\ \text { In the bulk: } \mathrm{Cl}_{2}+2 \mathrm{OH}^{-} \leftrightharpoons \mathrm{Cl}^{-}+\mathrm{ClO}^{-}+\mathrm{H}_{2} \mathrm{O} & & \text { (Equation 3) }\end{array}$

The cotton bleaching process also occurs through electrochemical reactions between the in situ electrogenerated oxidizer and the impurities or the pigments in the fabric. The oxidative bleaching process is responsible for degrading the components of the colored cotton matter, according to equation 4 (Vitero et al., 2017).

$\mathrm{ClO}^{-}+\mathrm{H}_{2} \mathrm{O}+$ Colored Matter $\leftrightharpoons \mathrm{Cl}^{-}+2 \mathrm{OH}^{-}+$Bleached Matter (Equation 4)

Based on the equations, it is possible to observe one of the advantages of the electrobleaching process based on hypochlorite in situ electrogeneration, when compared to the conventional process using the same oxidant. In the conventional bleaching process, the hypochlorite must be replenished when it is exhausted in the medium, which increases the costs and the waste volume of the process. However, in the electrogeneration process, hypochlorite is gradually generated in the environment, 
from chloride, which is a material of low toxicity and easy handling, and after the bleaching reaction between the hypochlorite and the colored matter (Equation 4), the reagents necessary for the continuity of the process are generated as a by-product of the process, and can again lead to the generation of more hypochlorite, according to Equation 1 (Ghalwa et al., 2012; Vitero et al., 2017). Figure 1 shows a schematic representation of the electrochemical process discussed above.

Figure 1. Schematic representation of the electrochemical process for the generation of hypochlorite.

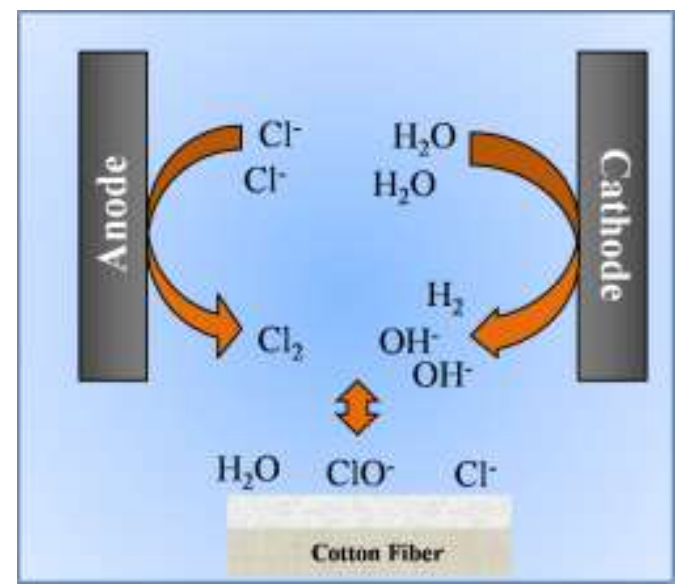

Source: Authors (2021).

\subsection{Optimization of the electrogeneration process}

In order to develop an efficient process, several parameters were evaluated such as the material and the surface of the electrode, the nature and the concentration of the electrolyte, the time of the process and the $\mathrm{pH}$ or the temperature of the reaction medium.

\subsubsection{Electrode evaluation}

The effect of different electrode materials on the production of $\mathrm{ClO}^{-}$was evaluated. The electrode materials, used in the electrochemical cell, should preferably present high overvoltage to oxygen, such as platinum, carbon and metal oxides (Sala \& Gutiérrez-Bouzán, 2012). The electrodes tested as candidate materials to be used as an anode consist of graphite (C), platinum $(\mathrm{Pt})$, stainless steel, tin/lead $(\mathrm{Sn} / \mathrm{Pb})$ and aluminum $(\mathrm{Al})$. All the tested materials are considered as good conductors, easily available and could be used in the electrolytic industry.

Carbon-based materials are safe from the environmental point of view and, in addition, have oxygenated functional groups on its surface which facilitate the exchange of electrons with organic substances (Bose et al., 2012). Thus, electrochemical tests were performed in the presence of the $\mathrm{C}$ as work electrode, $\mathrm{Pt}$ as counter electrode and $\mathrm{Ag} / \mathrm{AgCl}$ as reference. The results were unsatisfactory for the application of $\mathrm{C}$ electrode, because of the high exfoliation caused by the oxidation. This exfoliation caused the deposition of particles on the fabric surface even after washing with water.

The tests applying $\mathrm{Pt}$ and $\mathrm{Sn} / \mathrm{Pb}$ as work electrode achieved more attractive results. The data obtained in this preliminary stage allowed the definition of the Pt as the best electrode material for the remaining tests aiming the production of the oxidant in order to perform the bleaching process.

The effective areas of the attached anodes are listed in Table 1. These values are useful for normalizing the efficiency of the process, considering that the electrochemical process has a strong dependence on the electrode interface. The electrodes were positioned at a fixed distance between the cathode and the anode in order to avoid interference due to the drop in the ohmic potential of the electrolyte (for more details see experimental section) (Ghalwa et al., 2012; Saleem et al., 2012). 
Table 1. Dimensions of electrodes used in electrolytic cells.

\begin{tabular}{|c|c|}
\hline Electrode & Value \\
\hline \multicolumn{2}{|c|}{ Platinum } \\
\hline Geometric area $\left(\mathrm{cm}^{2}\right)$ & 13.0 \\
\hline Height $(\mathrm{cm})$ & 3.2 \\
\hline \multicolumn{2}{|c|}{$\mathrm{Sn} / \mathrm{Pb}$} \\
\hline Geometric area $\left(\mathrm{cm}^{2}\right)$ & 12.6 \\
\hline Height $(\mathrm{cm})$ & 20.0 \\
\hline \multicolumn{2}{|c|}{ Aluminum } \\
\hline Geometric area $\left(\mathrm{cm}^{2}\right)$ & 2.0 \\
\hline Height $(\mathrm{cm})$ & 2.0 \\
\hline \multicolumn{2}{|c|}{ Stainless steel } \\
\hline Geometric area $\left(\mathrm{cm}^{2}\right)$ & 2.3 \\
\hline Height $(\mathrm{cm})$ & 2.0 \\
\hline \multicolumn{2}{|c|}{ Carbon } \\
\hline Geometric area $\left(\mathrm{cm}^{2}\right)$ & 1.4 \\
\hline Height (cm) & 2.0 \\
\hline
\end{tabular}

Source: Authors (2021).

\subsubsection{Nature of the electrolyte}

Two salts, $\mathrm{NaCl}$ and $\mathrm{KCl}$, were evaluated as sources of chloride towards the production of $\mathrm{ClO}^{-}$and the effectiveness of the bleaching process. For this, electrolytic solutions of $\mathrm{NaCl}$ and $\mathrm{KCl}$ were used in the presence of the Pt electrode at room temperature, in aqueous medium and the presence or absence of auxiliary reactants.

Although the effects caused by the use of process auxiliary reactants have not been studied in this work, the data discussed suggest the importance of these products to obtain a more efficient process, as reported by Vitero and collaborators (2017). This is because in the presence of additives, a higher whiteness index was achieved due to the greater absorption of the solution by the fiber.

The observed results for the electrochemical methodology applying $\mathrm{NaCl}$ and $\mathrm{KCl}$ as source for $\mathrm{ClO}^{-}$can be observed in Table 2. These results are directly compared to those using the same reactants but without the application of any potential (control reactions). The comparison is as well carried out in the presence of auxiliary reactants, such as calcium and magnesium sequestrants and detergent emulsifier. The results prove the efficiency of the electrochemical application in the presence of the chloride source, since it is possible to observe an improvement in the degree of white with both $\mathrm{NaCl}$ or $\mathrm{KCl}$ (Table 2). Nevertheless, when $\mathrm{KCl}$ was the electrolyte and when in the presence of auxiliary reactants, the efficiency of the electrogeneration technique was not as effective as expected. In this case, a similar degree of white was observed when comparing the method using electrogeneration to the one without the application of any potential (control reaction). For the tests using $\mathrm{NaCl}$, the significant improvement in whiteness degree indicated the importance of the applied potential. This behavior observed for $\mathrm{NaCl}$ as an electrolyte indicates a higher effectiveness for the generation of $\mathrm{ClO}^{-}$, probably due to the small size of the $\mathrm{Na}^{+}$ion, which increases ion mobility (Ghalwa et al., 2012). 
Table 2. Whiteness degree obtained via hypochlorite electrogeneration from different electrolytes. ${ }^{\mathrm{a}}$

\begin{tabular}{ccccc}
\hline \multirow{2}{*}{ Electrolyte } & \multicolumn{3}{c}{ Whiteness Degree } \\
\cline { 2 - 5 } & \multicolumn{2}{c}{ No auxiliary reactants } & \multicolumn{2}{c}{ Addition of auxiliary reactants } \\
\cline { 2 - 5 } & Control Reaction $^{\mathrm{c}}$ & Electrochemical Reaction & Control Reaction $^{\mathrm{c}}$ & Electrochemical Reaction $^{\mathbf{b}}$ \\
\cline { 2 - 5 } $\mathrm{NaCl}$ & 21 & 26 & 28 & 43 \\
$\mathrm{KCl}$ & 18 & 28 & 33 & 34 \\
\hline
\end{tabular}

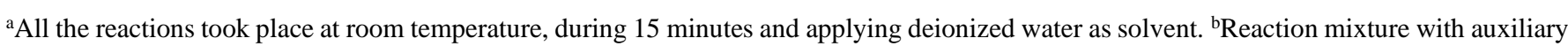
reactants included: $\mathrm{Pt}$ as work and counter electrode, $\mathrm{Ag} / \mathrm{AgCl}$ as reference electrode, $30 \mathrm{~g} / \mathrm{L}$ of the characteristic electrolyte, $1 \mathrm{~g} / \mathrm{L}$ of calcium and magnesium sequestrant, $2 \mathrm{~g} / \mathrm{L}$ of detergent/emulsifier. ${ }^{\mathrm{c} C o n t r o l}$ reactions are performed using the same reactants as the electrochemical reactions, but with no applied potential.

Source: Authors (2021).

\subsubsection{Effect of $\mathrm{pH}$ and reaction temperature}

The $\mathrm{pH}$ value plays an important role in the electrogeneration of $\mathrm{ClO}^{-}$. It was observed that the rate of $\mathrm{ClO}^{-}$generation increases as the $\mathrm{pH}$ value increases, since the reaction between chlorine and $\mathrm{OH}^{-}$favors the formation of $\mathrm{ClO}^{-}$according to Equation 3. The solutions proved to be more stable in $\mathrm{pH}$ values greater than 9.0, with the amount of $\mathrm{ClO}^{-}$in the medium increasing as the $\mathrm{pH}$ increases (Ghalwa et al., 2012).

When applying the same conditions as the experiments in Table 2, but with exchange of the solvent from deionized water to bicarbonate buffer ( $\mathrm{pH} 10$ ) a more satisfactory degree of white was observed (up to 15.79\%). Taking into account this observation, the tests presented in 3.2.4. were conducted applying bicarbonate buffer ( $\mathrm{pH} 10)$.

The tests were performed in $\mathrm{pH} 10$ because it is known that when $\mathrm{pH}$ ranges below 5.0-9.0 are applied there is a noticeable acceleration in the rate of cellulose degradation deteriorating the fiber surface (Farooq et al., 2013).

Besides the fabric degradation at low $\mathrm{pH}$ values, an increase in temperature is also associated with a decrease in the tensile strength of the cotton fabric (Farooq et al., 2013). Moreover, at temperatures above $35^{\circ} \mathrm{C}$, the hypochlorite tends to decompose chemically into chlorate (Ghalwa et al., 2012). Therefore, all tests were performed at room temperature.

\subsubsection{Effect of chloride salt concentration}

When applying electrogeneration, it is known that the increase in the amount of electrolyte tends to produce higher proportions of oxidizing agent in the solution. However, in order to make the process more efficient and economical, it is important to measure the sufficient concentration of electrolyte for the desired in situ production of hypochlorite, which causes the desired bleaching, without producing excess of the oxidizer (Vitero et al., 2017). Therefore, tests varying the concentrations of $\mathrm{NaCl}$ and $\mathrm{KCl}$ were also performed.

The results in terms of the whiteness degree following the application of different concentration of $\mathrm{NaCl}$ and $\mathrm{KCl}$ are presented in Table 3. These can be also compared to those from control reactions (reactions with no applied potential). The Figure 2 presents results for the whiteness degree as a function of the electrolyte concentration for both $\mathrm{NaCl}$ and $\mathrm{KCl}$. One can see from these data (Table 3 and Figure 2) that at lower electrolyte concentrations, such as $10 \mathrm{~g} / \mathrm{L}$ and $20 \mathrm{~g} / \mathrm{L}$, the bleaching was not effective. On the other hand, when higher quantities of the salts were applied ( $30 \mathrm{~g} / \mathrm{L}$ and $40 \mathrm{~g} / \mathrm{L})$ a significant difference in the whiteness levels were achieved. Despite the improvement in the degree of white when using a concentration of $40 \mathrm{~g} / \mathrm{L}$ for the two chlorides salts, the small difference obtained when compared to the application of $30 \mathrm{~g} / \mathrm{L}$ does not justify the use of a larger amount of $\mathrm{NaCl}$. Thus, $30 \mathrm{~g} / \mathrm{L}$ was considered as the optimum concentration for hypochlorite generation. 
Table 3. Whiteness degree obtained from hypochlorite electrogeneration at different concentrations of characteristic electrolyte. ${ }^{\text {a }}$

\begin{tabular}{|c|c|c|c|c|}
\hline \multirow{3}{*}{$\begin{array}{c}\text { Electrolyte } \\
\text { concentration } \\
\text { (g/L) }\end{array}$} & \multicolumn{4}{|c|}{ Whiteness Degree } \\
\hline & \multicolumn{2}{|c|}{$\mathrm{NaCl}$} & \multicolumn{2}{|c|}{$\mathrm{KCl}$} \\
\hline & Control Reaction $^{b}$ & $\begin{array}{c}\text { Electrochemical } \\
\text { Reaction }^{\mathrm{c}}\end{array}$ & Control Reaction $^{b}$ & $\begin{array}{c}\text { Electrochemical } \\
\text { Reaction }^{c}\end{array}$ \\
\hline 10 & 29 & 31 & 25 & 30 \\
\hline 20 & 25 & 28 & 29 & 30 \\
\hline 30 & 30 & 40 & 29 & 45 \\
\hline 40 & 28 & 42 & 26 & 54 \\
\hline
\end{tabular}

${ }^{\mathrm{a}}$ All the reactions took place at room temperature, during 15 minutes and applying bicarbonate buffer ( $\left.\mathrm{pH} 10\right)$ as solvent. ${ }^{\mathrm{b}} \mathrm{Control}$ reactions are performed using the same reactants as the electrochemical reactions, but with no applied potential. ${ }^{\mathrm{c}}$ Reaction mixture included: Pt as work and counter electrode, $\mathrm{Ag} / \mathrm{AgCl}$ as reference electrode, $10-40 \mathrm{~g} / \mathrm{L}$ of the characteristic electrolyte, $1 \mathrm{~g} / \mathrm{L}$ of calcium and magnesium sequestrant, $2 \mathrm{~g} / \mathrm{L}$ of detergent/emulsifier.

Source: Authors (2021).

Figure 2. Whiteness degree obtained via electrogeneration of hypochlorite from different concentrations of characteristic electrolyte in reaction time of 15 minutes.

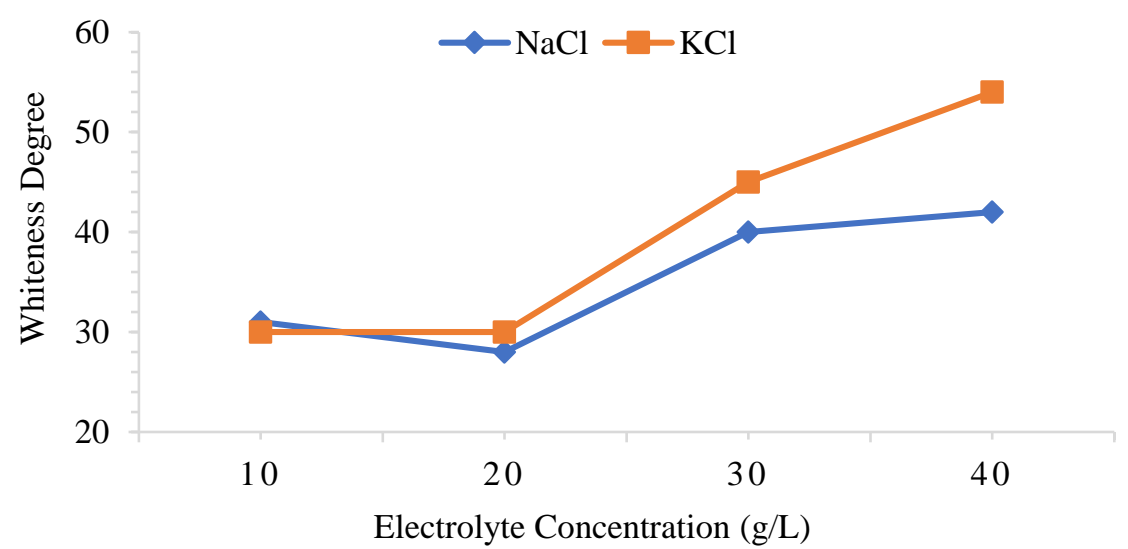

Source: Authors (2021).

\subsubsection{Effect of electrolysis time}

The time that the fabric will remain in contact with the bleaching solution is a crucial factor in carrying out the bleaching process. The literature demonstrates that the relationship linked to the amount of oxidizing agent is proportional to the improvement in the whiteness fabric (Abdel-Halim, 2012). In this way, tests were carried out applying the previous cited conditions, but varying the reaction time (15, 30, 45 and 60 minutes). The results made it possible to analyze how different reaction times interfered with the bleaching of the cotton fabric. The interval was chosen so that the processing time does not exceed the time used in conventional processes $(90 \mathrm{~min})$. The obtained results are presented in Table 4 in comparison with the results from the control reactions and, in Figure 3 by comparing electrochemical reactions applying the two different electrolytes. 
Table 4. Whiteness degree obtained with hypochlorite electrogeneration at different reaction times. ${ }^{\mathrm{a}}$

\begin{tabular}{ccccc}
\hline \multirow{2}{*}{$\begin{array}{c}\text { Time } \\
\text { (minutes) }\end{array}$} & \multicolumn{3}{c}{ NaCl } & \multicolumn{2}{c}{ KCl } \\
\cline { 2 - 5 } & Control Reaction $^{\mathbf{b}}$ & $\begin{array}{c}\text { Electrochemical } \\
\text { Reaction }^{\mathbf{c}}\end{array}$ & Control Reaction $^{\mathbf{b}}$ & $\begin{array}{c}\text { Electrochemical } \\
\text { Reaction }^{\mathbf{c}}\end{array}$ \\
\hline 15 & 30 & 40 & 23 & 44 \\
30 & 28 & 52 & 31 & 59 \\
45 & 24 & 32 & 64 \\
60 & 30 & 66 & 30 & 64 \\
\hline
\end{tabular}

${ }^{\mathrm{a}}$ All the reactions took place at room temperature, during 15-60 minutes and applying bicarbonate buffer ( $\left.\mathrm{pH} 10\right)$ as solvent. ${ }^{\mathrm{b}} \mathrm{Control}$ reactions are performed using the same reactants as the electrochemical reactions, but with no applied potential. ${ }^{c}$ Reaction mixture included: Pt as work and counter electrode, $\mathrm{Ag} / \mathrm{AgCl}$ as reference electrode, $30 \mathrm{~g} / \mathrm{L}$ of the characteristic electrolyte, $1 \mathrm{~g} / \mathrm{L}$ of calcium and magnesium sequestrant, 2 $\mathrm{g} / \mathrm{L}$ of detergent/emulsifier.

Source: Authors (2021).

Figure 3. Whiteness degree obtained via electrogeneration of hypochlorite at different reaction times in the presence of $30 \mathrm{~g} / \mathrm{L}$ of characteristic electrolyte.

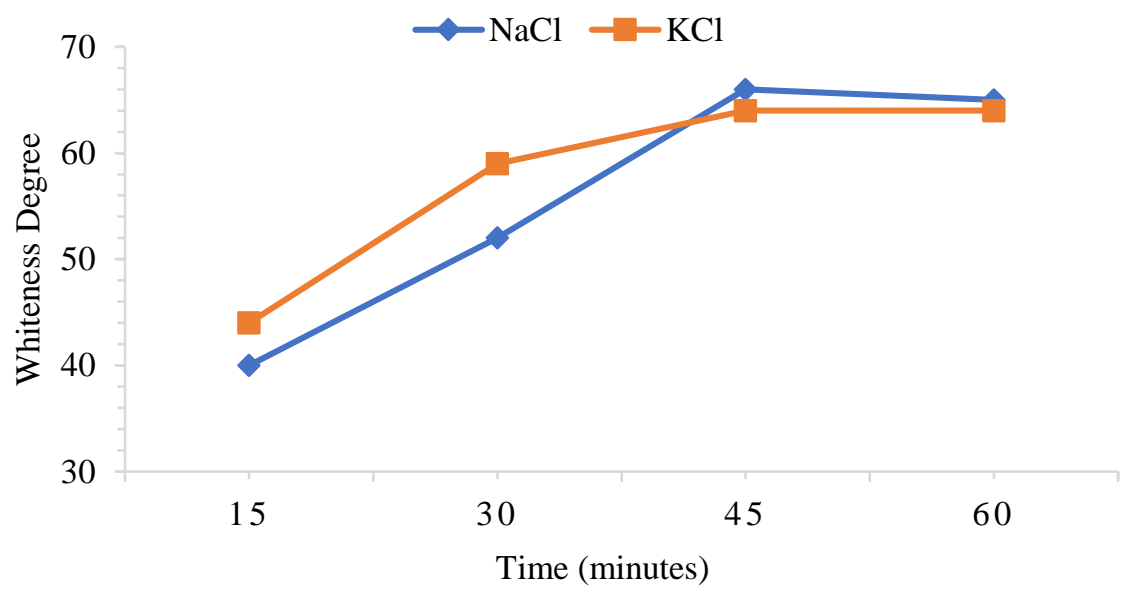

Source: Authors (2021).

After only 45 minutes of treatment, applying $\mathrm{NaCl}$ or $\mathrm{KCl}$, improvements in the whiteness of the raw fabric of $80.30 \%$ and $79.69 \%$ were observed, respectively. These results can be calculated by the comparation between the whiteness degree observed in the electrochemical reactions to those in control reactions. In all experiments it is possible to observe the efficiency of the application of electrochemical technique to the targeting system.

\subsection{Evaluation of residual hypochlorite}

The main advantage of electrochemical in situ production of hypochlorite is the generation of an environmentally safer process, since it does not require the transport or storage of hypochlorite liquor. The oxidant is generated from the salt containing chloride ion, which is a less toxic reagent (Das et al., 2016; Hage \& Lienke, 2005; Vitero et al., 2017). In addition, as the hypochlorite is gradually formed in the medium, it is possible to control the amount of oxidant produced.

In order to probe the amount of residual hypochlorite in the medium, an iodometric titration was carried out at the end of the bleaching process. The titration is able to measure the amount of active chlorine still available. 
The reactions applying $\mathrm{NaCl}$ and conducted during 45 minutes generated as waste an average value of active chlorine around $0.0744 \%$, after the bleaching of the fabric. When testing the reactions applying $\mathrm{NaCl}$ in 60 minutes experiment and as well as for the 45 and 60 minutes tests using $\mathrm{KCl}$, it was not possible to obtain the amount of active chlorine in the solution. The inability to detect active chloride at the end of the process suggests that the amount of $\mathrm{ClO}^{-}$generated in the medium was equivalent to the amount needed to whiten the tissue to the desired degree.

The cited results are of extremely importance, since they mean a reduction of waste generated after the bleaching process.

\subsection{Comparison of conventional and electrochemical method}

\subsubsection{Whiteness degree, time of reaction and temperature}

In order to better evaluate the efficiency of the investigated electrogeneration process, the results were directly compared to the conventional methods. The Table 5 presents the Berger's whiteness degree for the performed conventional methodology and for the new electrochemical one.

Table 5. Comparison of whiteness degree obtained via conventional bleaching and electrochemical generation of $\mathrm{ClO}^{-}$.

\begin{tabular}{ccc}
\hline Conventional bleaching & Whiteness degree & Reaction time (min) \\
\hline $\mathrm{H}_{2} \mathrm{O}_{2}{ }^{\mathrm{a}}$ & 68 & 60 \\
$\mathrm{NaClO}^{\mathrm{b}}$ & 71 & 60 \\
\hline Electrochemical bleaching $^{\mathbf{c}}$ & Whiteness degree & Reaction time (min) \\
\hline $\mathrm{NaCl}$ & 66 & 45 \\
$\mathrm{KCl}$ & 64 & 45 \\
\hline
\end{tabular}

aThe reaction mixture included $\mathrm{NaOH} 50 \%(3 \mathrm{~g} / \mathrm{L}), \mathrm{H}_{2} \mathrm{O}_{2} 50 \%(3 \mathrm{~g} / \mathrm{L})$, Iron sequestrant $(3 \mathrm{~g} / \mathrm{L})$ and detergent $(2 \mathrm{~g} / \mathrm{L})$ at $\mathrm{pH} 11$ for $60 \mathrm{~min}$ after increasing the temperature by $3{ }^{\circ} \mathrm{C} / \mathrm{min}$ to $90^{\circ} \mathrm{C}$.

${ }^{b}$ The reaction mixture included $\mathrm{NaOH} 50 \%$ (necessary to reach $\mathrm{pH} 9.5$ - approximately $0.5 \mathrm{~g} / \mathrm{L}$ ), $\mathrm{NaClO}$ (necessary to reach $3 \mathrm{~g} / \mathrm{L}$ active Chlorine - approximately $0.6 \mathrm{~g} / \mathrm{L})$ and detergent $(1 \mathrm{~g} / \mathrm{L})$ for 60 min at $25^{\circ} \mathrm{C}$. After this $\mathrm{NaHSO}_{3}(2 \mathrm{~g} / \mathrm{L})$ was added and the experiment carried out for more $30 \mathrm{~min}$ at $30^{\circ} \mathrm{C}$. ${ }^{\mathrm{c}}$ All the reactions took place at room temperature, during 45 minutes and applying bicarbonate buffer (pH 10) as solvent. Reaction mixture included: $\mathrm{Pt}$ as work and counter electrode, $\mathrm{Ag} / \mathrm{AgCl}$ as reference electrode, $30 \mathrm{~g} / \mathrm{L}$ of the characteristic electrolyte, $1 \mathrm{~g} / \mathrm{L}$ of calcium and magnesium sequestrant, $2 \mathrm{~g} / \mathrm{L}$ of detergent/emulsifier.

Source: Authors (2021).

The methodology presented in this work, using in situ electrogeneration of $\mathrm{ClO}^{-}$, requires shorter reaction times, lower temperature and produces a very similar degree of white when compared to the conventional method applying $\mathrm{H}_{2} \mathrm{O}_{2}$. The data presented in Table 5 also shows the diminishment of the reaction time (with a time interval 33.33\% smaller) when comparing to the conventional method applying $\mathrm{NaClO}$, while observing a very similar degree of white.

\subsubsection{Addition of oxidizing agent and residual chemicals}

A more detailed comparative analysis between the conventional method applying hypochlorite and the electrochemical methodology is summarized in Table 6. 
Table 6. Comparative analysis between conventional process using sodium hypochlorite and hypochlorite electrogeneration process. ${ }^{\mathrm{a}, \mathrm{b}}$.

\begin{tabular}{|c|c|c|c|c|c|c|}
\hline Method & $\begin{array}{c}\text { Reaction } \\
\text { time }\end{array}$ & pH & $\begin{array}{c}\text { Oxidizing } \\
\text { agent }^{\mathrm{c}}\end{array}$ & $\begin{array}{c}\text { Residual } \\
\text { hypochlorite }^{\mathrm{d}}\end{array}$ & Temperature & $\begin{array}{c}\text { Whiteness } \\
\text { degree }\end{array}$ \\
\hline Conventional & $60 \mathrm{~min}$ & 9.5 & $6 \%$ & $0.5 \%$ & $25-30{ }^{\circ} \mathrm{C}$ & 71 \\
\hline Electrochemical $(\mathrm{NaCl})$ & $45 \mathrm{~min}$ & 10 & - & $0.07 \%$ & $25^{\circ} \mathrm{C}$ & 66 \\
\hline Electrochemical $(\mathrm{KCl})$ & $45 \mathrm{~min}$ & 10 & - & 0 & $25^{\circ} \mathrm{C}$ & 64 \\
\hline
\end{tabular}

${ }^{a}$ The reaction mixture included $\mathrm{NaOH} 50 \%$ (necessary to reach $\mathrm{pH} 9.5-$ approximately $0.5 \mathrm{~g} / \mathrm{L}$ ), $\mathrm{NaClO}$ (necessary to reach $3 \mathrm{~g} / \mathrm{L}$ active Chlorine - approximately $0.6 \mathrm{~g} / \mathrm{L})$ and detergent $(1 \mathrm{~g} / \mathrm{L})$ for $60 \mathrm{~min}$ at $25^{\circ} \mathrm{C}$. After this $\mathrm{NaHSO}_{3}(2 \mathrm{~g} / \mathrm{L})$ was added and the experiment carried out for more $30 \mathrm{~min}$ at $30^{\circ} \mathrm{C} .{ }^{\mathrm{b}} \mathrm{All}$ the reactions took place at room temperature, during 45 minutes and applying bicarbonate buffer (pH 10) as solvent. Reaction mixture included: $\mathrm{Pt}$ as work and counter electrode, $\mathrm{Ag} / \mathrm{AgCl}$ as reference electrode, $30 \mathrm{~g} / \mathrm{L}$ of the characteristic electrolyte, $1 \mathrm{~g} / \mathrm{L}$ of calcium and magnesium sequestrant, $2 \mathrm{~g} / \mathrm{L}$ of detergent/emulsifier. ${ }^{\mathrm{C}}$ Amount of oxidizing agent added, percentage calculated using the weight of the material. ${ }^{\mathrm{d}}$ Quantity of the residual hypochlorite measured at the end of the reaction.

Source: Authors (2021).

One interesting observation is the fact that the process applying electrogeneration does not require the addition of the oxidizing agent, thus avoiding the transport of dangerous and unstable reagents and problems associated with prolonged storage of reagents containing chlorine. The storage can cause spontaneous decrease in the concentration of active chlorine (Das et al., 2016; Hage \& Lienke, 2005; Vitero et al., 2017).

A crucial fact to be noted is the difference in the amounts of residual hypochlorite in the medium after the processes. When applying the electrochemical process, the low residual content of the oxidizer excludes the need for a neutralization process, which would imply considerable savings in chemical costs and waste reduction.

Thus, the proposed alternative process, with $\mathrm{ClO}^{-}$electrogeneration, promotes reagent savings, reduces reaction time and allows the bleaching process to be carried out at a lower temperature than the conventional process. In addition to the associated improvements, the obtained whiteness index is very close to that obtained by the conventional method.

Besides that, as previously presented, the electrolyte used in the electrochemical method can be reused to continue the process of bleaching cotton fabrics. As discussed in Equation 4, after the hypochlorite bleaching action, the chloride is regenerated as a by-product of the bleaching process, showing the feasibility of using the process indefinitely, without the need for constant refill of the bleaching solution, as in the conventional method.

\subsubsection{Weight loss}

Weight loss was constantly monitored in order to analyze the loss of the fibrils, what probably means cellulose is being degraded and the substrate is having its properties altered. The weight loss usually observed in the standard procedures applying hydrogen peroxide is $4-4.5 \%$ in 60 minutes at $90{ }^{\circ} \mathrm{C}$ (Abdel-Halim \& Al-Deyab, 2011, 2013; Narendra, 2013). For the proposed methodology, applying electrogeneration of $\mathrm{ClO}^{-}$, the weight loss was $1 \%$, indicating a less damaging process.

\subsubsection{Hydrophilicity}

Hydrophilicity is an important characteristic of the fabric for later processes in the textile sector. The impurities, mainly non-cellulosic substances, on the raw fiber are responsible hydrophobic character (Demir et al., 2018; Montazer \& Morshedi, 2012). The raw fabric takes more than 600 seconds to absorb the drop of water. After application of the conventional bleaching processes the hydrophilicity decreases, it reaches 47 for the standard condition using $\mathrm{H}_{2} \mathrm{O}_{2}$ and 58 using NaClO. The optimized electrochemical processes showed an improvement in hydrophilicity of fabric samples (45-28 seconds). For example, the observed hydrophilicity was only 28 , after the bleaching process applying $30 \mathrm{~g} / \mathrm{L}$ of the $\mathrm{KCl}$ in 45 min of reaction. 


\section{Conclusion}

The results presented here for the in situ electrogeneration of $\mathrm{NaClO}$ and its application in the bleaching of cotton are promising. In order to better understand the electrobleaching process of cotton, different bleaching tests were carried out for the optimization of the process. The combination of the best results from the following evaluated parameters: electrolysis time, effect of nature and chloride salt concentration, effect of $\mathrm{pH}$ and reaction temperature, resulted in a faster and safer methodology.

In the presented methodology a mild condition was applied since the process was carried out at room temperature, with no addition of hazardous reactants, in shorter reaction time when compared with conventional methods and with no generation of residual $\mathrm{NaClO}$ in the medium. In summary, the best conditions with the electrochemical process were obtained using: platinum electrodes, $30 \mathrm{~g} / \mathrm{L} \mathrm{NaCl}$ as a chloride source, $\mathrm{pH} 10$ (bicarbonate buffer), room temperature $\left(\sim 25^{\circ} \mathrm{C}\right)$, and 45 minutes of electrogeneration. The presented electrochemical method was found to be comparable with the conventional one with respect to the Berger's whiteness degree, $66 \%$ in 45 min against $71 \%$ in 60 min, respectively. Besides that, this method showed an improvement in characteristics such as weight loss and hydrophilicity of the bleached fabric.

In addition, we can cite other advantages of the electrochemical bleaching method compared to the traditional method, starting with material savings, since there is no waste of reagents because the active species is generated in situ, without the need for continuous additions. There is less risk of storing the chemical compounds needed for the processes, as the methodology uses salt and water to produce $\mathrm{NaClO}$. Regarding the used electrodes, they are not materials of high cost or difficulty to be acquired, and they can be reused because are not being consumed in the process. Finally, the proposed methodology is ecofriendly because there is no production of water polluting chemicals, in addition to the fact that the process by-product can be reused for continuous generation of oxidizer.

The results presented here create a new perspective for methodologies for bleaching of cotton fabrics in a more innovative way and with the least possible impact, contributing to the continuous development in the textile processing industry.

Furthermore, it is important to mention that the development of the work brings as perspective the possibility of future studies for the investigation of other electrochemical systems for in situ production of other oxidizing agents besides hypochlorite for cotton bleaching, such as the hydroxyl radical. Thus, both new materials for the electrodes and the mechanism of generation of the species could be better investigated.

\section{References}

Abdel-Halim, E. S. (2012). Simple and economic bleaching process for cotton fabric. Carbohydrate Polymers, 88(4), 1233-1238. https://doi.org/10.1016/j.carbpol.2012.01.082

Abdel-Halim, E. S., \& Al-Deyab, S. S. (2011). Low temperature bleaching of cotton cellulose using peracetic acid. Carbohydrate Polymers, 86(2), 988-994. https://doi.org/10.1016/j.carbpol.2011.05.051

Abdel-Halim, E. S., \& Al-Deyab, S. S. (2013). One-step bleaching process for cotton fabrics using activated hydrogen peroxide. Carbohydrate Polymers, 92(2), 1844-1849. https://doi.org/10.1016/j.carbpol.2012.11.045

ABNT - Associação Brasileira de Normas Técnicas. (2008). NBR 10591: Materiais Têxteis - Determinação de Superfícies Têxteis.

ABNT - Associação Brasileira de Normas Técnicas. (1991). NBR 12060: Materiais Têxteis - Determinação do Número de Carreira/Cursos e Colunas em Tecidos de Malha.

ABNT - Associação Brasileira de Normas Técnicas. (1993). NBR 13000: Materiais Têxteis - Determinação da Hidrofilicidade de Tecido.

Bahtiyari, M. İ., \& Benli, H. (2019). Comparison of Ozone-Based Cold Bleaching Processes with Conventional Pretreatment of Cotton. Ozone: Science \& Engineering, 1-11. https://doi.org/10.1080/01919512.2019.1704218

Bose, S., Kuila, T., Mishra, A. K., Rajasekar, R., Kim, N. H., \& Lee, J. H. (2012). Carbon-based nanostructured materials and their composites as supercapacitor electrodes. Journal of Materials Chemistry, 22(3), 767-784. https://doi.org/10.1039/c1jm14468e

Chong, C. L. C. \& P. M. (1998). Bleaching cotton based on electrolytic production of hydrogen peroxide. American Dyestuff Reporter, 87(4), 13-19. 
Research, Society and Development, v. 10, n. 10, e318101018928, 2021

(CC BY 4.0) | ISSN 2525-3409 | DOI: http://dx.doi.org/10.33448/rsd-v10i10.18928

Ciobotaru, I., Ciobotaru, I., \& Vaireanu, D. (2020). Electrochemical production of active chlorine using platinised platinum electrodes. Technium, 2, $12-16$.

Das, D., Patra, A. K., Jakhar, R., \& Sunder, S. (2016). Electrochemical bleaching of cotton. Indian Journal of Fibre and Textile Research, 41(2), 217-220.

Demir, A. G., Oliveira, F. R., Gulumser, T., \& Souto, A. P. (2018). New Possibilities of Raw Cotton Pre-treatment before reactive dyeing. IOP Conference Series: Materials Science and Engineering, 460(1). https://doi.org/10.1088/1757-899X/460/1/012026

Farooq, A., Ali, S., Abbas, N., Fatima, G. A., \& Ashraf, M. A. (2013). Comparative performance evaluation of conventional bleaching and enzymatic bleaching with glucose oxidase on knitted cotton fabric. Journal of Cleaner Production, 42, 167-171. https://doi.org/10.1016/j.jclepro.2012.10.021

Ghalwa, N. A., Tamos, H., ElAskalni, M., \& Agha, A. R. El. (2012). Generation of sodium hypochlorite (NaOCl) from sodium chloride solution using C/PbO 2 and $\mathrm{Pb} / \mathrm{PbO} 2$ electrodes. International Journal of Minerals, Metallurgy and Materials, 19(6), 561-566. https://doi.org/10.1007/s12613-012-0596-0

Hage, R., \& Lienke, A. (2005). Applications of transition-metal catalysts to textile and wood-pulp bleaching. Angewandte Chemie - International Edition, 45(2), 206-222. https://doi.org/10.1002/anie.200500525

Liu, K., Zhang, X., \& Yan, K. (2018). Bleaching of cotton fabric with tetraacetylhydrazine as bleach activator for H2O2. Carbohydrate Polymers, 188, 221227. https://doi.org/10.1016/j.carbpol.2018.01.111

Montazer, M., \& Morshedi, S. (2012). Nano photo scouring and nano photo bleaching of raw cellulosic fabric using nano TiO2. International Journal of Biological Macromolecules, 50(4), 1018-1025. https://doi.org/10.1016/j.ijbiomac.2012.02.018

Narendra G, A. S. (2013). Accelerated Bleaching of Cotton Material with Hydrogen Peroxide. Journal of Textile Science \& Engineering, 03(04). https://doi.org/10.4172/2165-8064.1000140

Sala, M., \& Gutiérrez-Bouzán, M. C. (2012). Electrochemical techniques in textile processes and wastewater treatment. International Journal of Photoenergy, 2012. https://doi.org/10.1155/2012/629103

Saleem, M., Chakrabarti, M. H., Hasan, D. B., Islam, M. S., Yussof, R., Hajimolana, S. A., Hussain, M. A., Khan, G. M. A., \& Si Ali, B. (2012). On site electrochemical production of sodium hypochlorite disinfectant for a power plant utilizing seawater. International Journal of Electrochemical Science, 7(5), 3929-3938.

Shetti, N. P., Malode, S. J., Malladi, R. S., Nargund, S. L., Shukla, S. S., \& Aminabhavi, T. M. (2019). Electrochemical detection and degradation of textile dye Congo red at graphene oxide modified electrode. Microchemical Journal, 146(January), 387-392. https://doi.org/10.1016/j.microc.2019.01.033

Griesbach, U., Maars, S., Stecker, F., Fischer, A. (2016). Electrochemical textile-Washing process. (United States Patent No. US9,435,073 B2). United States Patent.

Vitero, F., Monllor, P., Bonet-Aracil, M., Morallon, E., \& Quijada, C. (2017). Electrobleaching of cotton fabrics in sodium chloride solution. Vlakna a Textil, $24(2), 32-36$.

Yu, D., Wu, M., Lin, J., \& Zhu, J. (2018). Economical Low-Temperature Bleaching of Cotton Fabric Using an Activated Peroxide System Coupling Cupric Ions with Bicarbonate. Fibers and Polymers, 19(9), 1898-1907. https://doi.org/10.1007/s12221-018-7963-Z 